IJPSR (2011), Vol. 2, Issue 3

(Research Article)
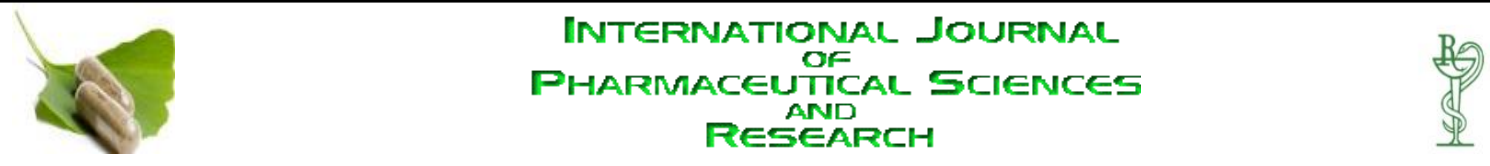

Received on 02 November, 2010; received in revised form 21 January, 2011; accepted 02 February, 2011

\title{
DEVELOPMENT AND VALIDATION OF RP-HPLC METHOD FOR QUANTITATIVE ESTIMATION OF RITONAVIR IN BULK AND PHARMACEUTICAL DOSAGE FORMS
}

\section{K. Chiranjeevi* and K. P. Channabasavaraj}

Department of Pharmaceutical Analysis, Bharathi College of Pharmacy, Bharathi Nagara, Mandya (District), Karnataka, India

Keywords:

Ritonavir, RP-HPLC,

Pharmaceutical Dosage Form, Validation

Correspondence to Author:

Chiranjeevi Kakaraparthy

Department of Pharmaceutical Analysis, Bharathi College of Pharmacy, Bharathi Nagara, Mandya (District), Karnataka, India

\section{ABSTRACT}

A simple, precise, specific and accurate reverse phase HPLC method has been developed for the determination of Ritonavir in bulk and pharmaceutical dosage forms. The chromatographic separation was achieved on Symmetry C18 $(4.6 \times 100 \mathrm{~mm}, 3.5 \mu \mathrm{m})$ column using a mixture of Buffer: Acetonitrile (50:50) as the mobile phase at a flow rate 1.0 $\mathrm{ml} / \mathrm{min}$. Linearity was observed in concentration range of $50-150 \mu \mathrm{g} / \mathrm{ml}$. The retention time of Ritonavir was $5.1 \mathrm{~min}$. The analyte was monitored using UV detector at $239 \mathrm{~nm}$. Results of analysis were validated statistically and by recovery studies. The method was validated according to the $\mathrm{ICH}$ guidelines with respect to specificity, linearity, accuracy, precision and robustness. 
INTRODUCTION: Ritonavir ${ }^{1}$ is an antiretroviral drug from the protease inhibitor class used to treat HIV infection and AIDS. Ritonavir is frequently prescribed with Highly Active Anti-Retroviral Therapy, not for its antiretroviral action, but as it inhibits the same host enzyme that metabolizes other protease inhibitors. This inhibition leads to higher plasma concentrations of these latter drugs, allowing the clinician to lower their dose and frequency and improving their clinical efficacy. It has the structural formula and shown in (Fig. 1).

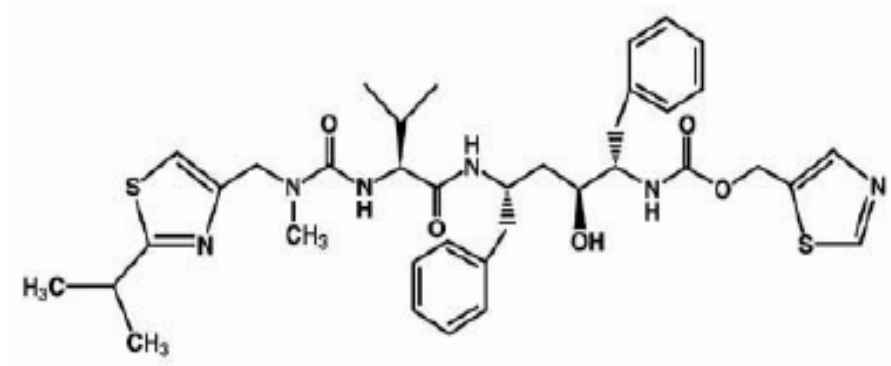

FIG. 1: CHEMICAL STRUCTURE OF RITONAVIR

The chemical name of Ritonavir is (5S, 8S, 10S, 11S) - 10- hydroxy- 2- methyl- 5- (1- methylethyl) - 1- [2(1-methylethyl) - 4- thiazolyl] - 3, 6-dioxo- 8, 11- bis (phenylmethyl)-2, 4, 7, 12- etraazatridecan- 13-oic acid 5-thiazolyl methyl ester. It is official in Indian Pharmacopoeia ${ }^{2}$ and United States Pharmacopoeia 3 . From the literature survey, it was found that Ritonavir estimated by analytical methods such as Reversed Phase High Performance Liquid Chromatographic (RP-HPLC) method 4, 5, 6, 7, 8, 9, 10, LC-MS ${ }^{11}$ and HPTLC method ${ }^{12}$. The developed method was simple, precise, specific and accurate. The statistical analysis proved that method is reproducible and selective for the analysis of Ritonavir in bulk drug and tablet formulations.

MATERIALS AND METHODS: A Shimadzu HPLC model containing LC-20 AT pump, variable wavelength programmable UV / VIS detector and Rheodyne injector was employed for the investigation. All the chemicals used in the investigation were of HPLC grade. The chromatographic analysis was performed on a Symmetry C18 $(4.6 \times 100 \mathrm{~mm}, 3.5 \mu \mathrm{m})$ column. The mobile phase consisted of buffer (Phosphate $\mathrm{pH}_{4}$ ) and acetonitrile in the ratio of 50:50 (v/v). The optimized chromatographic conditions are summarized in Table 1.

TABLE 1: OPTIMIZED CHROMATOGRAPHIC CONDITIONS FOR THE PROPOSED METHOD

\begin{tabular}{cc}
\hline Parameters & Optimized condition \\
\hline Column & Symmetry C18 $(4.6 \times 100 \mathrm{~mm}, 3.5 \mu \mathrm{m})$ \\
Mobile phase & Buffer (Phosphate $\mathrm{pH}-4)$ and Acetonitrile \\
& $(50: 50)$ \\
Flow Rate & $1.0 \mathrm{ml} / \mathrm{min}$ \\
Injection volume & $20 \mu \mathrm{l}$ \\
Detection & $239 \mathrm{~nm}$ in UV detector \\
Temperature & Ambient \\
Retention Time & $5.10 \mathrm{~min}$ \\
Run time & $8 \mathrm{~min}$ \\
\hline
\end{tabular}

Preparation of mobile phase: Potassium dihydrogen orthophosphate was weighted (3.5 g) and dissolved in $500 \mathrm{ml}$ of HPLC water. This solution was mixed with $500 \mathrm{~mL}$ of acetonitrile and mixed well and finally adjusted $\mathrm{pH} 4.0$ using ortho phosphoric acid. The solution was sonicated for 10 min and filtered using Whatmann filter paper.

Preparation of standard stock solution of Ritonavir: The standard solution of Ritonavir was prepared by dissolving $25 \mathrm{mg}$ of Ritonavir $100 \mathrm{ml}$ of Mobile phase to give the concentration $250 \mu \mathrm{g} / \mathrm{ml}$. The mobile phase and the solution were sonicated for $10 \mathrm{~min}$ and filtered through $0.45 \mu \mathrm{m}$ filter.

Preparation of Calibration Curve: From the standard stock solution, the various dilutions of Ritonavir in the concentration of 50, 75, 100, 125 and $150 \mu \mathrm{g} / \mathrm{ml}$ were prepared. The solutions were injected using a $20 \mu \mathrm{l}$ fixed loop in to the chromatographic system at the flow rate of 1.0 $\mathrm{ml} / \mathrm{min}$ and the effluents were monitored at 239 $\mathrm{nm}$, chromatograms were recorded. The Ritonavir was eluted at $5.1 \mathrm{~min}$ as shown in (Fig. 2). The 
calibration curve was constructed by plotting average peak area versus concentration and was presented in (Fig. 3). The method was extended for determination of Ritonavir in pharmaceutical dosage form containing $100 \mathrm{mg}$.

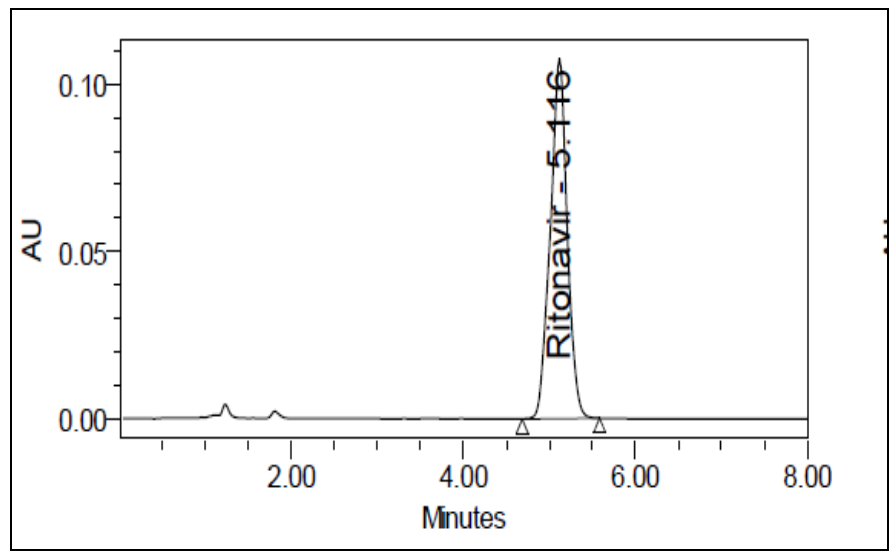

FIG. 2: TYPICAL RP-HPLC CHROMATOGRAM OF RITONAVIR BY THE PROPOSED METHOD

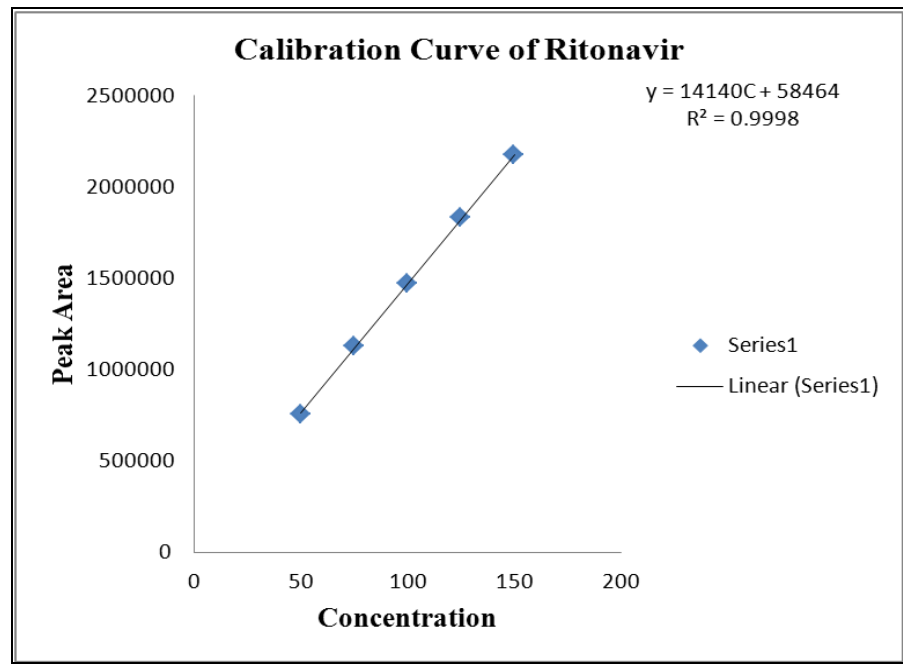

FIG. 3: CALIBRATION CURVE OF RITONAVIR BY THE PROPOSED METHOD

Preparation for analysis of marketed formulations: For the estimation of Ritonavir in tablets formulations, 20 tablets of two different brands were weighed and triturate to fine powder. Tablet powder equivalent to $100 \mathrm{mg}$ of Ritonavir for each was weighed and transfer into $100 \mathrm{ml}$ volumetric flask than dissolved with methanol and further diluted with methanol. It was kept for ultra- sonication for $30 \mathrm{~min}$; this was filtered through Whatmann filter paper No. 41 and then final dilution was made with methanol to get the final stock solution of $1000 \mu \mathrm{g} / \mathrm{ml}$. From this stock solution, various dilutions of the sample solution were prepared and analyzed. The proposed methods were validated as per the $\mathrm{ICH}$ guidelines 13-15

RESULTS AND DISCUSSION: A system suitability test was applied to representative chromatograms for various parameters. The results obtained were within acceptable limits and are represented in Table 2. Thus, the system meets suitable criteria. The calibration curve was obtained for a series of concentration in the range of $50-150 \mu \mathrm{g} / \mathrm{ml}$ and it was found to be linear. The data of regression analysis of the calibration curves are shown in Table 3. The precision was measured in terms of repeatability, which was determined by sufficient number of aliquots of a homogenous sample. The $\%$ RSD was found and lying with in 2.

TABLE 2: SYSTEM SUITABILITY TEST PARAMETERS FOR THE PROPOSED METHOD

\begin{tabular}{cc}
\hline Parameters & Values \\
\hline Theoretical plates & 2945.50 \\
Tailing factor & 0.98 \\
Retention Time & 5.01 \\
\hline
\end{tabular}

TABLE 3: REGRESSION ANALYSIS OF THE CALIBRATION CURVE FOR THE PROPOSED METHOD

\begin{tabular}{cc}
\hline Parameters & Values \\
\hline Linearity Range $(\mu \mathrm{g} / \mathrm{ml})$ & $50-150$ \\
Correlation coefficient $\left(\mathrm{r}^{2}\right)$ & 0.9998 \\
Regression equation & $\mathrm{Y}=14140 \mathrm{C}+58464$ \\
Slope & 14140 \\
Intercept & 58464 \\
\hline
\end{tabular}

This showed that the precision of the method was satisfactory. The accuracy of the method was inferred by establishing the precision and linearity studies of the standard. The \% RSD was less than 2.0. This showed that the recoveries of Ritonavir by 
the proposed methods are satisfactory. Ruggedness and Robustness were determined and the \% RSD values were calculated from precision study was less than 2.0. Limit of detection (LOD) and Limit of quantitation (LOQ) were determined by the proposed methods. The results of validation parameters are summarized in Table 4 . The results of tablet analysis and recovery studies obtained by the proposed method were validated by statistical evaluation and are given in Table 5.

TABLE 4: SUMMARY OF VALIDATION PARAMETERS FOR THE PROPOSED METHOD

\begin{tabular}{|c|c|c|c|}
\hline \multicolumn{3}{|c|}{ Parameters } & Values \\
\hline \multicolumn{3}{|c|}{ Limit of detection $(\mu \mathrm{g} / \mathrm{ml})$} & 0.013 \\
\hline \multicolumn{3}{|c|}{ Limit of quantitation $(\mu \mathrm{g} / \mathrm{ml})$} & 0.43 \\
\hline \multicolumn{4}{|c|}{${ }^{a}$ Precision ( \% RSD) } \\
\hline \multicolumn{3}{|c|}{ Intra Day precision } & 0.35 \\
\hline \multicolumn{3}{|c|}{ Inter Day precision } & 0.22 \\
\hline \multicolumn{4}{|c|}{${ }^{a}$ Ruggedness ( \% RSD) } \\
\hline \multicolumn{3}{|c|}{ Analyst I } & 0.11 \\
\hline \multicolumn{3}{|c|}{ Analyst II } & 0.06 \\
\hline \multicolumn{4}{|c|}{${ }^{a}$ Robustness (\% RSD) } \\
\hline \multicolumn{4}{|c|}{ Changed condition I ( ratio of mobile phase) } \\
\hline \multicolumn{3}{|c|}{$55: 45$ (Buffer : Acetonitrile) } & 0.20 \\
\hline \multicolumn{3}{|c|}{$45: 55$ (Buffer : Acetonitrile) } & 0.29 \\
\hline \multicolumn{4}{|c|}{ Changed condition II ( flow rate of mobile phase) } \\
\hline \multicolumn{3}{|c|}{$0.8 \mathrm{ml} / \mathrm{min}$} & 0.38 \\
\hline \multicolumn{3}{|c|}{$1.2 \mathrm{ml} / \mathrm{min}$} & 0.06 \\
\hline \multicolumn{4}{|c|}{$\begin{array}{l}\text { Mean of six determinations, RSD indicates relative Standard } \\
\text { deviation }\end{array}$} \\
\hline \multirow{2}{*}{\multicolumn{4}{|c|}{$\begin{array}{l}\text { TABLE 5: ASSAY RESULTS OF RITONAVIR USING PROPOSED } \\
\text { METHOD }\end{array}$}} \\
\hline & & & \\
\hline $\begin{array}{l}\text { Brand } \\
\text { used }\end{array}$ & $\begin{array}{l}\text { Labelled amount } \\
\qquad(\mathrm{mg})\end{array}$ & $\begin{array}{l}\text { Amount } \\
\text { found (mg) }\end{array}$ & \%Recovery $\pm S D^{* *}$ \\
\hline Tab-A & 100 & 99.78 & $99.65 \pm 0.11$ \\
\hline Tab-B & 100 & 100.20 & $100.23 \pm 0.06$ \\
\hline
\end{tabular}

CONCLUSION: Thus, it can be concluded that the method developed in the present investigation was simple, sensitive, accurate, rugged, robust, rapid and precise. Hence, the above said method can be successfully applied for the estimation of Ritonavir in pharmaceutical dosage forms.
ACKNOWLEDGEMENT: We would like thank to Matrix laboratories, Hyderabad for providing reference sample of Ritonavir to facilitate this work and also to the Principal Dr T. Tamizh Mani, Bharathi College of Pharmacy for providing facilities.

\section{REFERENCES:}

1. www.rxlist.com

2. Indian Pharmacopoeia, vol. III, 2007, 1058.

3. United States Pharmacopoeia 30, National Formulary 25, 2007, 3143

4. Richard $M$, Hoetelmans W, Marjolijn Van Essenberg, Monique Profijt, Pieter L. Meenhorst, Jan W. Mulder, et al. High-Performance Liquid Chromatographic determination of Ritonavir in human plasma, cerebrospinal fluid and saliva. Journal of Chromatography B: Biomedical Sciences and Applications 1998; 705(1):119-126.

5. Rebiere Herve, Mazel Bernard, Civade Corinne, Bonnet Pierre-Antoine. Determination of 19 antiretroviral agents in pharmaceuticals or suspected products with two methods using High-Performance Liquid Chromatography. Journal of chromatography B 2007; 850:376-383.

6. Yekkala RS, Ashenafi D, Marien I, Xin H, Haghedooren E, Hoogmartens $\mathrm{J}$ et al. Evaluation of an International Pharmacopoeia method for the analysis of Ritonavir by Liquid Chromatography. Journal of pharmaceutical and biomedical analysis 2008; 48(3):1050-4.

7. Veronica Albert, Pilar Modamio, Cecilia FL and Eduardo LM. Determination of Saquinavir and Ritonavir in human plasma by RP-HPLC and the analytical error function. Journal of Pharmaceutical and Biomedical Analysis 2004; 36(4):835-840.

8. Usami Yoshiko, Tsuyoshi OK, Naka Masahiko, Sagisaka Masafumi, Kaneda Tsuguhiro. A simple HPLC method for simultaneous determination of Lopinavir, Ritonavir and Efavirenz. Journal-Chemical and pharmaceutical bulletin 2003; 51:715-718.

9. Dias $\mathrm{CL}$, Rossi RC, Donato EM, Bergold $\mathrm{AM}$ and Froehlich PE. LC Determination of Ritonavir, a HIV Protease Inhibitor, in Soft Gelatin Capsules. J chromatographia 2005; 62:589-593.

10. Proust V, Toth K, Hulin A, Taburet AM, Gimenez F, Singlas E. Simultaneous High-Performance Liquid Chromatographic determination of the antiretroviral agents' Amprenavir, Nelfinavir, Ritonavir Saquinavir, Delavirdine and Efavirenz in human plasma. Journal of chromatography B 2000; 742:453-458.

11. Temghare GA, Shetye SS, Joshi SS. Rapid and Sensitive Method for Quantitative Determination of Lopinavir and Ritonavir in Human Plasma by Liquid ChromatographyTandem Mass Spectrometry. E-Journal of Chemistry 2009; 6(1):223-230. 
12. Sulebhavikar AV, Pawar UD, Mangoankar KV, Prabhunavelkar ND. HPTLC Method for Simultaneous Determination of Lopinavir and Ritonavir in Capsule Dosage Form. E-Journal of Chemistry 2008; 5(4):706-712.

13. International Conference on Harmonization (ICH), Validation of Analytical Procedures: Text on Validation of Analytical Procedures Q2A, 1994.
14. International Conference on Harmonization (ICH), Validation of Analytical Procedures: Methodology Q2B, 1996.

15. International Conference on Harmonization (ICH), Validation of Analytical Procedures: Text and Methodology Q2 (R1), 2005. 